\title{
Review on Regional Water Resources Assessment Models under Stationary and Changing Climate
}

\author{
C.-Y. XU $\mathrm{XU}^{1,3, *}$ and V. P. SINGH ${ }^{2}$ \\ ${ }^{1}$ Department of Earth Sciences, Hydrology, Uppsala University, Villavägen 16, S-75236 Uppsala, \\ Sweden; ${ }^{2}$ Department of Civil and Environmental Engineering, Louisiana State University, Baton \\ Rouge, Louisiana 70803-6405, U.S.A.; ${ }^{3}$ Nanjing Institute of Geography and Limnology, Chinese \\ Academy of Sciences, Nanjing, P. R. China \\ (*author for correspondence, e-mail: Chong-yu.Xu@hyd.uu.se)
}

(Received: 2 June 2003; in final form: 2 May 2004)

\begin{abstract}
A comprehensive assessment of the water resources available in a region or a river basin is essential for finding sustainable solutions for water-related problems concerning both the quantity and quality of the water resources. Research on the development and application of water balance models at different spatial and temporal scales has been carried out since later part of the 19th century. As a result, a great deal of experience on various models and methods has been gained. This paper reviews both traditional long-term water balance methods and the new generation distributed models for assessing available water resources under stationary and changing climatic conditions at different spatial and temporal scales. The applicability and limitations of the methods are addressed. Finally, current advances and challenges in regional- and large-scale assessment of water resources are presented.
\end{abstract}

Key words: climate change, hydrologic models, regional scale, review, water balance, water resources assessment

\section{Introduction}

An assessment of the available water resources is a pre-requisite to undertake an analysis of the stress on the water resources and to subsequently adopt appropriate management strategies to avoid adverse environmental effects and reconcile conflicts between users. During the last five decades there has been a sharp increase in water consumption owing to the population explosion, unprecedented rise in standard of living, and enormous economic development. The situation has become even more difficult because of the increasing pollution of water resources. This, in turn, has caused serious problems impeding sustained economic and social development in many regions, even those not located in arid zones. These problems are caused not only by natural factors, such as uneven precipitation in space and time, but also by mismanagement and the lack of knowledge about existing water resources. A study, 'Comprehensive Assessment of Freshwater Resources of the World' undertaken by WMO and partner agencies (Hultcrantz, 1997), has 
confirmed that there is insufficient knowledge of exactly how much water is available. This situation poses difficulties for effective regional, national, and international water resources management. Moreover, the situation becomes even more complicated by the looming climate change which, in the longer term, has the potential to decrease the availability of natural water resources in many areas of the world due to probable changes in the rainfall distribution and the increase in temperature.

The objective of this paper is to review the existing methods/models for assessing regional water resources under stationary and changing climate conditions at different spatial and temporal scales, identify the progress and challenges that remain and discuss the possible further developments in the field. It is hoped that the paper will be a useful reference to those hydrologists and water resources engineers who are working in the field of water resources assessment at different levels for various purposes. However, this paper is not intended to discuss all individual methods/models that have appeared in the literature; instead, representative methods/models are discussed.

The article is organized as follows. Introducing the objective of the paper in Section 1, it first reviews in Section 2 the methods for simulating water resources under stationary climate conditions, which include the long-term water balance methods, conceptual lumped-parameter models and spatial hydrologic GIS supported models. Methodologies for assessing hydrological responses to global climate change are reviewed and discussed in Section 3. Five methods are classified and discussed which include the use of direct GCM-derived hydrological output, the method of coupling GCMs and macroscale hydrologic models, the use of dynamic downscaling, the use of statistical downscaling and the use of hypothetical scenarios as input to hydrological models. Problems related to calibration and validation of different models are discussed in Section 4. In Section 5 methods of prediction on ungauged basins, i.e., regionalisation methods are discussed. A general discussion on the progress and challenges is presented in Section 6.

\section{Water Resources Modelling under Stationary Climate}

In 1995, Singh edited a book that summarized 26 popular models from around the globe. Seven years later, Singh and Frevert (2002a, b) published two volumes, a and b, containing a large number of popular mathematical models of respectively large and small watershed hydrology and applications. In the same year, Singh and Woolhiser (2002) provided a historical perspective of mathematical modelling of watershed hydrology and discussed new developments and challenges in watershed modelling, including data acquisition; model components; model construction, calibration and verification; analysis of risk and reliability. 


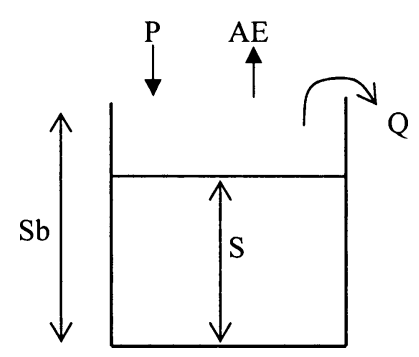

Figure 1. Simple lumped bucket model. $\mathrm{Sb}$ is the bucket capacity, $\mathrm{S}$ is the storage in the bucket.

\subsection{LONG-TERM WATER BALANCE METHOD}

A traditional way for water resources assessment is based on the long-term average water balance equation (say one year or many years) over a basin as

$$
P=A E+Q
$$

where $P, A E$ and $Q$ are the long-term average annual precipitation, actual evapotranspiration and streamflow, respectively. The concept embodied in Equation (1) can be represented by a simple lumped bucket model (Figure 1). In order to solve the Equation (1) and calculate the available water resources, Q, two terms P and AE, must be known. The areal precipitation $\mathrm{P}$ is usually computed from point measurements. The key element in the long-term water balance of a catchment or a region is the value of the actual long-term evapotranspiration, AE. In order to calculate this value, we can relate the changes in actual evapotranspiration to the changes in precipitation and potential evapotranspiration, PE. The upper limit of the AE is either P or PE and depends on the following two extremes. In the case where precipitation is much less than the potential evapotranspiration, on the annual or longer time scale, all incoming precipitation is evaporated back. The first limiting condition occurs

$$
A E=P \quad \text { and } \quad Q=0
$$

We see that the actual evapotranspiration rate is controlled by the amount of rainfall, regardless of how high PE is. Thus this is a "water limited" system. For the other case where precipitation is much greater than the potential evapotranspiration, we would have the second limiting condition:

$$
A E=P E \quad \text { and } \quad Q=P-A E
$$

Here the upper limit to actual evapotranspiration is the evaporation demand (or energy available for evaporation), and this is an "energy limited" system. 
The variation of precipitation and potential evapotranspiration throughout the year and from year to year results in variations in the soil moisture content and consequently a value of $A E$ intermediate between these limiting relationships occurs. In such a case, the ratio $A E / P$ is represented as a function of $P E / P$. There are several such methods in the literature, of which Schreiber (1904) and Ol'dekop in (1911) are the earliest. Budyko (1955) and Budyko and Zubenok (1961), [see also Dooge (1992)], carried out empirical analysis of the climate and water balance of a large number of catchments around the world and showed that they all fitted a unique curve on the $A E / P E$ versus $P / P E$ and found that these data fell within the limits of the formula proposed by Schreiber in 1904 (Equation 4) and that proposed by Ol'dekop in 1911 (Equation 5).

$$
\begin{aligned}
& \frac{A E}{P E}=\frac{P}{P E}\left[1-\exp \left(-\frac{P E}{P}\right)\right] \\
& \frac{A E}{P E}=\tanh \left(\frac{P}{P E}\right)
\end{aligned}
$$

The method proposed by Budyko and Zubenok is closely approximated by the simpler formula proposed by Turc (1954), which was somewhat modified later by Pike (1964) on the basis of further measurements:

$$
\frac{A E}{P E}=\frac{\frac{P}{P E}}{\sqrt{1+\left(\frac{P}{P E}\right)^{2}}}
$$

The three relations of Schreiber, Ol'dekop and Turc-Pike are shown in Figure 2.

The annual water-balance method for estimating renewable water resources from meteorological data, although very simple, has a number of disadvantages. First, in arid and semiarid regions, the absolute value of the river runoff is very small and close to the error of determination of evaporation and precipitation. Second, it is impossible to obtain estimates of water resources which are crucial for modern planning of seasonal and monthly water resources management.

\subsection{LUMPED CONCEPTUAL WATER BALANCE MODELS}

A large number of conceptual, lumped rainfall runoff models have been developed and used since the middle of the last century. Catchment water balance is the principal concept and soil moisture accounting is the central issue for these models. Daily time resolution is normally used, and monthly time resolution is also used if the sole objective is to estimate the seasonal water yield.

The general structure of all water balance models is similar and building such a model involves writing equations that relate the rates of water storage change 


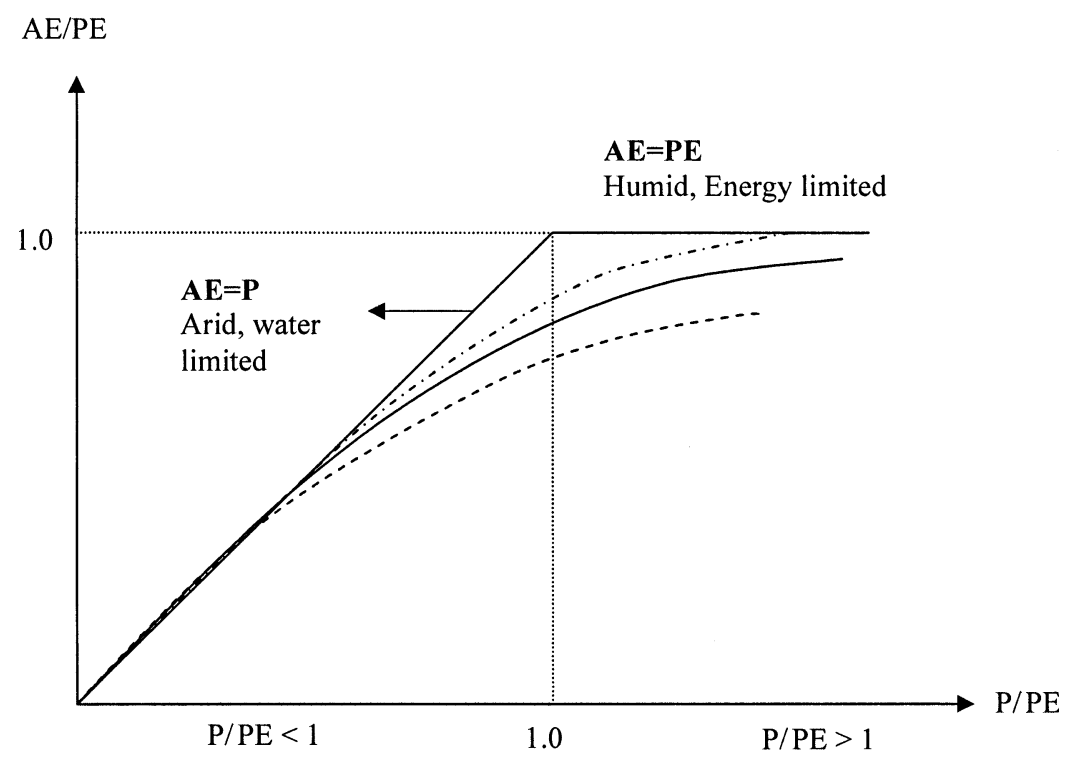

Figure 2. Long-term actual evapotranspiration as presented by Turc-Pike (mid), and Schreiber (lower) and Ol'dekop (upper) methods.

within the control volume to flows of water across the control surface. A simple soil water balance model for a control volume drawn around a block of soil is:

$$
S(t+1)=S(t)+P(t)-A E(t)-Q(t)
$$

in which $S(t)$ represents the amount of soil moisture stored at the beginning of the time interval $t, S(t+1)$ the storage at the end of that interval, and the flow across the control surface during the interval consists of precipitation $P(t)$, actual evapotranspiration, $A E(t)$, and soil moisture surplus, $Q(t)$, which supplies streamflow and groundwater recharge. Solving this equation requires dealing with time series of the four variables: $S, P, A E, Q$, and possibly of other variables related to them.

Conceptual precipitation models involve estimation of areal values from point measurements and calculation of snowmelt for a given time step. In most applications of conceptual snow models, a temperature index method, i.e., degree-day method is commonly used. In case where more climatologic and meteorologic data are available, energy balance approaches with different degrees of simplifications are also used.

The water balance models differ in how $A E$ and $Q$ are conceptually considered and mathematically represented. In order to estimate the actual evapotranspiration in the soil-water budget method many investigators have used a soil-moisture extraction function or coefficient of evapotranspiration which relates the actual rate of evapotranspiration $A E$ to the potential rate of evapotranspiration $P E$ based on 
some function of the current soil moisture content and moisture retention properties of the soil. A general form of such functions can be shown as

$$
A E=P E \cdot f\left(\frac{S M T}{S M C}\right)
$$

where SMT is the actual soil moisture storage and SMC is the soil moisture storage at field capacity. Dyck (1983) provided a summary of some moisture extraction functions used by different investigators. Mintz and Walker (1993) also illustrated several moisture extraction functions. Many researchers agree on the general pattern of the soil's behavior that moisture is extracted from the soil at the potential rate until some critical moisture content is reached when evapotranspiration is no longer controlled by meteorological conditions. Below this critical moisture content, there is a linear decline in soil moisture extraction until the wilting point is reached. This type of behavior is illustrated by Shuttleworth (1993) and Dingman (1994). Shuttleworth (1993), notes that the critical moisture content divided by the field capacity is typically between 0.5 and 0.8 . This type of moisture extraction function is also used in the HBV model (e.g. Bergström, 1992) where actual evapotranspiration is computed as

$$
A E=P E \cdot \frac{S M T}{L P \cdot F C}
$$

where FC is the field capacity and LP is a parameter ranging $0.5-0.8$.

There are several drawbacks to using simple soil moisture extraction functions. Mintz and Walker (1993), cited field studies that show $f\left(\frac{S M T}{S M C}\right)$ may vary not only for a given soil wetness but may also vary with leaf-area index. In addition, it is difficult to determine the spatial variation of the water-holding capacity. A new and surely better approach to determine the relationship between plant transpiration and potential evapotranspiration is to correlate $f\left(\frac{S M T}{S M C}\right)$ with satellite-derived indices of vegetation activity so that $f\left(\frac{S M T}{S M C}\right)$ will reflect the plant growth stage and spatial vegetation patterns.

In order to select a method for modelling stream discharge, $Q$, it is essential to recognize the different runoff components and their regime. The number of runoff components to be analyzed depends on the characteristics of the basin and the objective of the component separation including the time base to be considered. In most conceptual lumped catchment models, the following four components (left) or even the right two components, in case of monthly water balance computation, may be identified and modelled explicitly:

$$
\left.\begin{array}{l}
\left.\begin{array}{l}
\text { surface flow } \\
\text { fast interflow }
\end{array}\right\} \text { fast components } \\
\begin{array}{l}
\text { slow interflow } \\
\text { base flow }
\end{array}
\end{array}\right\} \text { slow components }
$$


A lumped approach to the modelling of runoff considers the catchment as a spatially singular entity which transforms rainfall excess into an outflow hydrograph. The approach ranges from the use of a mathematical transfer function, or "black-box" approach, to modelling of significant hydrological processes and their interrelationships. Fleming (1975) briefly discussed how hydrologic models commonly handle various hydrologic processes. The usual method is to consider soil moisture content as resident in one or more storages or reservoirs. The following storage concepts might be applied:

$$
\begin{aligned}
\text { single linear reservoir } \quad S=K^{\prime} Q & \rightarrow Q=K \cdot S \\
\text { single logarithmic reservoir } \quad S=K^{\prime} \ln Q & \rightarrow Q=K \cdot e^{S} \\
\text { single nonlinear reservoir } \quad S=K^{\prime} Q^{m} & \rightarrow Q=K \cdot S^{1 / m}
\end{aligned}
$$

where $S=$ storage; $Q=$ reservoir outflow (discharge); $K$ and $K^{\prime}=$ storage constants; and $m=$ exponent. The storage is usually updated by a balance equation specified for each storage zone.

Many lumped catchment models use the above concepts and the procedure varies from seasonal to shorter than one day time step. Monthly water balance models were first developed in the 1940s by Thornthwaite (1948) and have since been adopted, modified, and applied to a wide spectrum of hydrological problems (e.g., Alley, 1984; Schaake and Liu, 1989; Xu et al., 1996). A general review on monthly water balance models being used all over the world is made by Xu and Singh (1998).

Many conceptual lumped-parameter models with one day or shorter time resolutions have been developed since the 1960s with the initial objective of flood forecasting in river basins. They have since been used for simulation purposes for hydrologic design and water resources assessment at different scales. A few representative models will be briefly mentioned below as examples and for a more complete account the cited references should be referred to.

The Stanford Watershed Model IV, developed by Crawford and Linsley (1964), represents the first great success in combining all the main hydrologic processes within a computer model. This model is widely known and has been applied to many catchments throughout the world. Several models have since followed, developing the concept further. A frequently used model in this group is the Sacramento Soil Moisture Accounting Model (Burnash et al., 1973). This model has been used by many researchers as one of the standard tools in the United States for flood forecasting, water resources assessment, and studies on the impact of climate change. The HBV model (e.g., Bergström, 1976) is widely used in the Nordic countries as a standard tool to forecast stream floods, assess surface water resources, and simulate the climate change effects. Applications of the HBV models have been made in some 30 countries (Bergström, 1992). In China and other far east Asian countries, the Xinanjiang model is used as a standard tool for a number of hydrologic simulation purposes. The model was developed in 1973 and published in international 
journals in 1980 (Zhao et al., 1980; Zhao, 1992). It has also been successfully used in many other countries including the United States, Germany, Belgium, France, and Sweden.

Many other models, having a similar structure but with different process conceptualisations, have been used in many regions of the globe (See also Leavesley, 1994). Among others, the Institute of Royal Meteorology Belgium model (Bultot and Dupriez, 1976) has been applied to basins in Belgium (Bultot et al., 1988) and Switzerland (Bultot et al., 1992). The HYDROLOG model (Porter and McMahon, 1971) was applied to two basins in South Australia (Nathan et al., 1988). The Hydrologic Simulation Program - FORTRAN (HSPF) model (U.S.E.P.A., 1984) has been applied to a basin in Newfoundland, Canada (Ng and Marsalek, 1992). The ARNO model (Todini, 1996) first tested on the Arno basin has since been used as part of a real-time flood forecasting system, as a tool for investigating land use changes and as an approach to the evaluation of land-surface-atmosphere interactions at general circulation model (GCM) scale.

\subsection{SPATIAL HYDROLOGY MODELS - A GIS SUPPORTED MODELLING SYSTEM}

According to Maidment (1996), a spatial hydrology model is one which simulates the water flow and transport in a specified region of the earth using GIS data structures. Motivation for using such models includes: First, for a variety of operational and planning purposes, water resources managers responsible for large regions need to estimate the spatial variability of resources over large areas at a spatial resolution finer than the one that can be provided by observed data alone. Second, hydrologists and water managers are interested in the effects of land-use and climate variability and change over a large geographic domain. Third, there is an increasing need for using hydrologic models as a base to estimate point and non-point sources of pollution loading to streams. To fulfil the above requirements a new generation of distributed models is required. These models differ not only from the lumped conceptual models since the spatial distribution has to be considered, but also from the existing physically-based distributed models developed for a detailed investigation in small catchments, such as the SHE model, since they are to be applied to large areas with different climate. On the one hand, they require that the equations and parameters should be physically relevant so that determination of parameters values from spatial data is possible. On the other hand, they should not be too specific with respect to local conditions, some kind of generality and averaging is required. The model parameters should be fewer than the ones in traditional distributed models for small experiment catchments, because the data used to determine parameters might not be readily available in other regions.

The current popularity of the rainfall-runoff model, TOPMODEL, is a direct result of the widespread availability of catchment GIS systems and particularly of digital terrain maps. The TOPMODEL is a variable contributing area conceptual model in which the predominant factors determining the formation of runoff are 
represented by the topography of the basin and a negative exponential law linking the transmissivity of the soil with the vertical distance from the ground level. In this model the total flow is calculated as the sum of two terms: surface runoff and flow in the saturated zone. Surface runoff, in the most recent versions of the model, is in turn the sum of two components, the first generated by infiltration excess and the second, referring to a variable contributing area, by the saturation excess mechanism. Although a conceptual model, i.e., one in which the physical reality is represented in a simplified manner, the TOPMODEL is frequently described as being 'physically based', in the sense that its parameters can be measured directly in situ (Beven and Kirkby, 1979).

Two approaches are used in the subdivision of a catchment each with its own advantages and disadvantages: (1) to subdivide the catchment into so-called "hydrological response units" which are similar with regards to selected characteristics and which are modelled separately (e.g., Arnold et al., 2000; Becker and Braun, 1999); (2) to subdivide the catchment into equally-spaced square grid elements (e.g., Arnell, 1999; Matheussen et al., 2000; Yao and Hashino, 2001). Problems related to the first approach include which characteristics should be considered relevant to the hydrologic process. If there are too many, the partitioning will be very detailed; if too few, we neglect the heterogeneity of the others. Problems related to the second approach are that the physical characteristics within each grid cell may be heterogeneous. Reducing size of the grid cell reduces heterogeneity but increases computation. There is therefore a need to study how and to what extent a river basin must be disaggregated into sub-areas characterized by differences in land use, land cover, topography, etc.

\section{Water Resources Assessment under Changing Climate}

One of the most important impacts of future climatic changes on society will be the changes in regional water availability. Such hydrologic changes will affect nearly every aspect of human well-being, from agricultural productivity and energy use to flood control, municipal and industrial water supply, fishery and wildlife management. The tremendous importance of water in both society and nature underscores the necessity of understanding how a change in global climate could affect regional water supplies. It is not surprising that the hydrological literature now abounds with regional-scale hydrologic simulations under greenhouse scenarios. Due to the mismatch between the climate models and the hydrological need (Table I), simulation of the hydrological impact of climate change includes the use of climate models (which simulate climatic effects of increasing atmospheric concentration of greenhouse gases), hydrological models (which simulate hydrological impacts of changing climate), and downscaling techniques (which link climate models and application-scale hydrological models). Literature survey shows that the following methods have been used by various researchers in simulating hydrologic impact of global climate change (see Figure 3). 
Table I. Some existing gaps between GCMs' ability and hydrology need (from Xu, 1999c)

\begin{tabular}{llll}
\hline & Better simulated & Lesswell-simulated & Not well-simulated \\
\hline Spatial scales & Global & Regional & Local \\
Mismatch & $500 \times 500 \mathrm{~km}$ & $50 \times 50 \mathrm{~km}$ & $0-50 \mathrm{~km}$ \\
$\begin{array}{l}\text { Temporal scales } \\
\text { Mismatch }\end{array}$ & $\begin{array}{c}\text { Mean annual } \\
\text { and seasonal }\end{array}$ & Mean monthly & Mean daily \\
$\begin{array}{l}\text { Vertical scale } \\
\text { Mismatch }\end{array}$ & $500 \mathrm{hPa}$ & $800 \mathrm{hPa}$ & Earth surface \\
Working variables & Wind & Cloudiness & Evapotranspiration \\
Mismatch & Temperature & Precipitation & Run-off \\
& Air pressure & Humidity & Soil moisture \\
\hline $\begin{array}{l}\text { GCMs' ability declines.- } \\
\text { Hydrological importance increases. }\end{array}$ \\
\hline
\end{tabular}

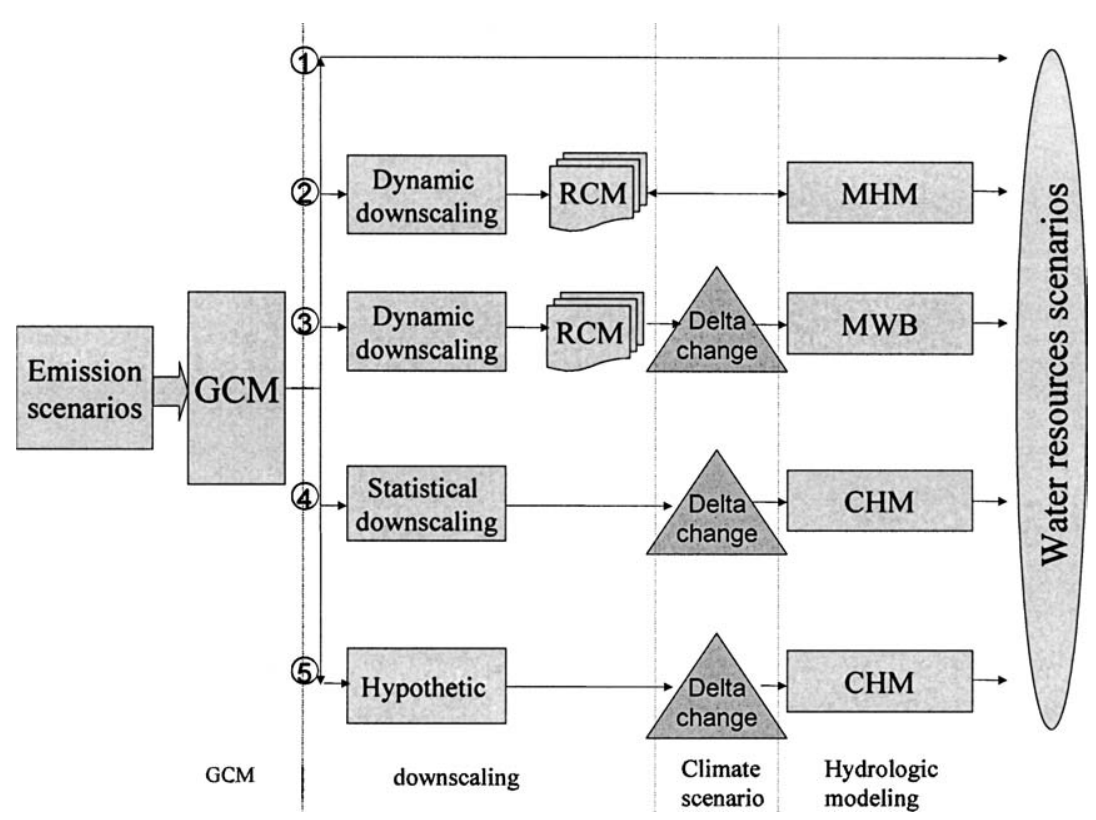

Figure 3. Schematic representation of the methods for assessing water resources under changing climate. In the figure, GCM is the global circulation model, RCM the regional climate model, MHM the macroscale land-surface hydrological model, MWB the macroscale water balance model, CHM the catchment-scale hydrological model. Definitions of various model types are given in Section 3.

The first idea is to directly use the GCM-derived hydrological output. A GCM model typically has four component models: atmospheric, land surface, ocean and sea ice. As the four models are interactive, production runs must include all four model components. Initially, the atmospheric model was developed to a relatively 
high level of sophistication, whilst the land phase and the ocean component models were very simplistic. Runoff enters into current GCM model simulations at two points (Rowntree, 1989). Firstly, at the boundary between the atmosphere and the land surface, where flux transfers are converted into surface runoff, and secondly at the boundary between the ocean and land, where inflow hydrographs are required as input to the ocean model. At present neither is simulated with sufficient accuracy. Kite et al. (1994) have demonstrated some of the problems associated with GCM modelling of the hydrological cycle, particularly the lack of adequate lateral transfer of water. Therefore, even if the GCMs were able to simulate the water excess correctly, they would still be operating with an incomplete hydrological cycle.

The second and third methods, i.e., simulation of water resources using GCMs produced hydroclimatic data as input to macroscale hydrologic models, has been carried out on the world's largest river basins. Two types of macroscale hydrological models are currently being developed. The first type is macroscale water balance models, MWB, (e.g., "Macro-PDM" of Arnell, 1999) which hold the concept of water balance and provide no coupling with GCMs and running "off-line". The second type is macroscale land-surface hydrological models, MHM, (e.g. VIC model of Liang et al., 1994) which have a primary purpose of helping to improve the land surface hydrologic characteristics of global climate models, regional climate models and meso-scale meteorological models. Compared with the first type of models, the MHM uses the energy balance as its primary concept and it could be two-way coupled with GCMs/RCMs, and therefore it could run with smaller time steps. A discussion of the critical issue involved in MHM can be found in Vörösmarty et al. (1993), Wood (1991), Wilkinson (1993) and Dolman et al. (2001).

Two approaches have been used in developing MHM: The first is improving the energy balance process within an existing hydrological model and enabling it to couple with an atmospheric model (e.g., Liang et al., 1994) and the second is improving the hydrological processes in land surface models developed for atmospheric models (Kim et al., 2001). The water balance equation and energy balance equation at the land surface are connected through the rate of evapotranspiration since it appears in both equations. This gives yet another method to estimate evapotranspiration, i.e., considering it as the residual in the energy balance equation.

Examples of such studies are those of Liston et al. (1994) who used a twolinear-reservoir routing model with daily precipitation and potential evaporation from several GCMs to simulate flows in the Mississippi River Basin. The routing model used grid boxes $2^{\circ}$ latitude by $2.5^{\circ}$ longitude. Kite et al. (1994) combined a hydrological model (the SLURP model) with a GCM for a macroscale watershed. A water balance was carried out at 12-hour time intervals for a 10-year period using the Canadian Climate Centre GCM II data set for grid points within and surrounding the $1.6 \times 10^{6} \mathrm{~km}^{2}$ Mackenzie River Basin in north-eastern Canada. The water surpluses from each relevant grid point were accumulated to provide a simulated hydrograph at the outlet of the river. 
Nash and Gleick (1993) studied the hydrological impact of climate change on the Colorado River basin in the western United States. Several GCMs were used to simulate the climate over the Colorado River for double $\mathrm{CO}_{2}$ conditions. Precipitation and temperature predictions from both the GCMs as well as from hypothetical scenarios were then input to the National Weather Service River Forecasting and Simulation (NWSRFS) hydrologic model to simulate the river basin hydrologic cycle, including runoff. By linking atmospheric, hydrologic, and river simulation models Nash and Gleick (1993) were able to assess the potential impact of greenhouse warming in the Colorado River basin. Wood et al. (1992), Liang et al. (1994) and Nijssen et al. (1997) used the variable infiltration capacity (VIC) macroscale hydrologic model and implemented it in GCMs to simulate streamflow of large river basins. Although the model is formulated for a fully coupled application within a GCM, it can also be run "off-line" using observed energy and water fluxes as forcings.

The results of these studies showed that coupling the hydrological model with GCMs produces a better representation of the recorded flow regime than GCM-based predictions of runoff for large river basins. However, to simulate the flow regime of small to median sized catchments, the methods 3 to 5 are needed (Figure 3).

The method and 4 consists of three steps: (i) The future climate scenarios are simulated by a global climate model, GCM, (ii) the simulated climate scenarios are further downscaled into local or regional climate scenarios with a statistical tool, and (iii) the resulting local or regional climate scenarios are used to run a suitably tested catchment-scale hydrologic model, CHM to provide future hydrologic scenarios or predictions. Studies using such methods include Wilby et al. (1994), among others.

The fifth method, i.e., the use of hypothesized scenarios as input to hydrological models, is also widely used, because at the present time it is not possible to use precipitation outputs from GCMs directly as input to hydrological models. The climate models give different values of climate variables changes and hence do not provide a single reliable estimate that could be advanced as a deterministic forecast for hydrological planning. Various hypothetical climate change scenarios have been adopted and climate predictions for 'double $\mathrm{CO}_{2}$ ' conditions have become a standard (e.g., Loaiciga et al., 1996). This method consists of the following stages: (1) Determine the parameters of a hydrological model in the study catchment using current climatic inputs and observed river flows for model validation. (2) Perturb the historical time series of climatic data according to some climate change scenarios (typically, $\Delta T=+1,+2$ and $+4^{\circ} \mathrm{C}$ and $\Delta P=0, \pm 10 \%, \pm 20 \%$ ). (3) Simulate the hydrological characteristics of the catchment under the perturbed climate using the calibrated hydrological model. (4) Compare the model simulations of the current and possible future hydrological characteristics.

There are a great number of studies that use such altered time series to assess possible effects of climate change. To mention a few of them, Nemec and Schaake (1982) used the Sacramento model on two catchments in the US. Arnell (1992) 
used the Thornthwaith water balance model on 15 catchments in UK. Vehviläinen and Lohvansuu (1991) used the HBV model on 19 Scandinavia catchments. Xu (2000) used the NOPEX water balance model on 26 catchments in central Sweden.

It is necessary to make clear at this juncture that the climate change scenarios used in the above studies should not necessarily be seen as the most likely future climates in the region: they are primarily designed to show the hydrologic sensitivity to climate change within a reasonable interval.

\section{Calibration and Validation Methods}

General methodologies, related to model calibration, verification, and validation, have been a subject of considerable discussion and dispute during the past decade, e.g., by Beven (1989), Oreskes et al. (1994) and many others. Most of the scientific discussion has been of a principal nature and few authors, such as Klemes (1986), Anderson and Woessner (1992), IAHR (1994), Refsgaard and Knudsen (1996) and $\mathrm{Xu}$ (1999a), have attempted to outline general rigorous operational procedures.

Klemes (1986) considered the general problem of validating catchment hydrological models and proposed a testing framework. The proposed scheme is called hierarchical because the modelling tasks are ordered according to their increasing complexity, and the demands of the test increase in the same direction. Four major categories, corresponding to modelling tasks and test methods, are summarized in Table II.

Simple split-sample testing involves dividing the available measured time-series data for the test catchment into two sets, each of them should be used in turn for calibration and validation, and results from both arrangements compared. For differential split-sample testing, the same approach is followed, but the data are divided according to rainfall rate or some other variable in an attempt to show that the model has general validity in that it can predict the values of the output variables for conditions different from those for which it was calibrated. For example, if the model is intended to simulate streamflow for a wet climate scenario then it should

Table II. Hierarchical scheme for operational testing of hydrologic simulation models (after Klemes, 1986)

\begin{tabular}{|c|c|c|c|c|}
\hline & \multicolumn{2}{|c|}{ Stationary conditions } & \multicolumn{2}{|c|}{ Transient conditions } \\
\hline & $\mathrm{B} \operatorname{asin} \mathrm{A}$ & Basin B & Basin A & Basin B \\
\hline Basin A & Split-sample test & Proxy-basin test & $\begin{array}{l}\text { Differential } \\
\text { split-sample test }\end{array}$ & $\begin{array}{l}\text { Proxy-basin } \\
\text { differential } \\
\text { split-sample test }\end{array}$ \\
\hline Basin B & Proxy-basin test & Split-sample test & $\begin{array}{l}\text { Proxy-basin } \\
\text { differential } \\
\text { split-sample test }\end{array}$ & $\begin{array}{l}\text { Differential } \\
\text { split-sample test }\end{array}$ \\
\hline
\end{tabular}


be calibrated on a dry set of the historic record and validated on a wet set. If it is intended to simulate flows for a dry climatic scenario, the opposite should be done. In general, the model should demonstrate its ability to perform under the transition required: from drier to wetter conditions or the opposite. Proxy-catchment tests use data for two catchments. These tests can be used to show that the model has even greater general validity, as they involve calibrating the model against data for one catchment and then running a validation test using data for the other catchment. For differential proxy-catchment testing, the available measured time-series data for each catchment are divided into two sets according to rainfall intensity or some other variable. The model is then calibrated against one of the sets (e.g., the dry period data for the first catchment) and a validation test run using a contrasting set (e.g., the wet period data for the second catchment). Calibration is required in all the four validation methods discussed above.

Beven et al. (1984) and Loague (1990) used another type of test in which the model is not calibrated, and predictions are simply compared against measurements. Ewen and Parkin (1996) proposed a method, namely a 'blind' approach. The central feature of this method is that it involves making predictions for a test catchment as if it were a hypothetical catchment. The modeller is, therefore, not allowed sight of the output data for the test catchment (i.e., the method involved 'blind' testing), and, as a result, cannot calibrate the model for the test catchment.

Traditional validation methods are usually limited to comparing simulated and measured streamflows, while many other fluxes and storages are simulated. This is especially true for spatially distributed models, for which multivariable and multiscale validation procedures are needed. Literature survey shows that during the 1960 s to 1980 s much attention was given to specific procedures for parameter assessment, calibration (e.g., Rosenbrock, 1960; Pickup, 1977; Sorooshian et al., 1983; Hendrickson et al., 1988, and many more) and, to a lesser extent, validation of conceptual models. From the 1990s onwards more studies discuss the importance of multicriterion and how to formulate efficient multiobjective equations (e.g., Ambroise et al., 1995; Wen and Lee, 1998; Seibert, 2000).

Validation of distributed models is much more complicated and difficult as compared with validation of lumped conceptual models (e.g., Refsgaard, 1997), since application of distributed models often requires several thousands of grid points, each of which is characterized by a number of parameters and variables. The problems related to initialization, calibration and validation of distributed models are summarized by Rosso (1994): "In principle, spatially distributed models can accept experimental data at each grid element or calculation node. In practice, because of heterogeneity of parameter values, differences between measurement scales and model grid scales, and experimental constraints, the specification of parameter values is very difficult. These constraints also apply to the validation of distributed model predictions by using measurement of internal system response. Conventional strategies for distributed model validation typically rely on the comparison of simulated model variables to observed data for specific points representing either 
external boundaries or intermediate locations on the model grid. . . traditional validation based on comparing simulated with observed outflows at the basin outlet still remains the only attainable option in many practical cases. However, this method is poorly consistent with spatially distributed modeling..."

\section{Prediction on Ungauged Basins}

Application of hydrological models (both lumped and distributed) on ungauged catchments or regions, i.e., estimation of model parameters from physical characteristics of catchments, is a key issue identified by the hydrological community through the IAHS Decade on Prediction in Ungauged Basins (PUB). It has also been identified as a high priority by the Global Energy and Water Experiment (GEWEX) of WCRP. It has also been recognized as a difficult field in hydrologic research. At more than 30 years ago, Nash and Sutcliffe (1970, p. 282) stated that "few hydrologists would confidently compute the discharge hydrograph from rainfall data and the physical description of the catchment, nevertheless, this is a practical problem which must often be faced by practising engineers". Since then, a number of attempts have been made. Different approaches have been used for conceptual lumped models at catchment scale which include: Proxy-basin method (e.g., Klemes, 1986; Xu, 1999a), (2) Linear interpolation methods (e.g., Bergström, 1990), (3) Kriging interpolation methods (e.g., Vandewiele and Elias, 1995), (4) univariate multiple regression (e.g., James, 1972; Jarboe and Haan, 1974; Magette et al., 1976; Weeks and Ashkanasy, 1983; Servat and Dezetter, 1993; Seibert, 1999; Xu, 1999b; Müller-Wohlfeil et al., 2003, and many others), (5) multivariate regression (e.g., Tung et al., 1997), and (6) one step regression - regional calibration (e.g. Fernandez et al., 2000). Previous studies achieved some progress but the problem is far from solved. As Abdulla and Lettenmaier (1997a) pointed "regionalization of the parameters of rainfall-runoff models for prediction at ungauged catchments is not an easy task". Similar conclusion was also made in the study of Xu (1999b): "The problem of parameter estimation still constitutes the largest obstacle to the successful application of rainfall-runoff models. Clearly, from an operational point of view, the full benefit of a conceptual model will only be realised to the extent that it is possible to synthesise data for ungauged catchments. It is therefore appropriate to continue research in this aspect".

During the last decade, the evolution of continental-scale hydrology for water resources assessment at large scale and for improvement of the representation of land-surface hydrological processes in regional and global atmospheric models has placed new demands on hydrologic modellers. The key issue in the development and application of macro-scale hydrological models is how to derive model parameter values from spatial data set without calibrating the model on the large scale is. Moreover, new types of hydrological models work on rectangular grids at large scale which makes the regionalization study even a more difficult task, because calibration of hydrologic models over a large area especially on the rectangular 
cells is not feasible. A well established suitable method has not been available. In the previous applications of large-scale hydrological models, all or part of the parameters have been determined in one of the following ways: (1) Fixed globally at "reasonable values", or values selected from literature for the appropriate land cover or from previous studies. Examples of applications using these approaches include Wood et al. (1992), Stamm et al. (1994), Nijssen et al. (1997), Arnell (1999) and Ma et al. (2000). (2) Calibrate the model on a number of catchments and regional parameters are obtained by interpolation (e.g., Guo et al.; 2001; Gottschalk et al., 2001). (3) Direct estimation from physical data for some parameters and calibration for the remaining parameters (e.g., Watson et al., 1999). And (4) Develop multiple regression equations that relate physical characteristics and model parameters that are optimised on the selected sub-catchments, and use the equations to estimate model parameters for the grid cell in large areas (e.g., Abdulla and Lettenmaier 1997a, b; Kite et al., 1994; Xu, 2003). Previous studies have shown that existing regionalization procedures must be improved. The uncertainty induced by transferring the regionalization scheme from small to large scales, from basin to rectangular grid area, and from one geographic/climatic region to another have to be properly tested and quantified.

\section{Progress and Challenges}

It is now well accepted that modelling seems to be the only resort to address complex environmental and water resources problems. More and more people are using models these days and models will continue to find increasing use in the entire gamut of water resources planning, development, assessment, and management (e.g. Maidment, 1996).

- Many hydrologic analyses are still performed using lumped conceptual models where it may be sufficient to estimate catchment outflow.

- As the demand placed on hydrologic models for environmental decision making has increased, particularly for problems involving prediction of future hydrologic conditions resulting from changes in land use or climate (e.g., Matheussen et al., 2000), the use of distributed (both physically-based and conceptual) models in environmental analysis is becoming more common in recent years.

- The present-generation computer models are more integrated and they simulate, in addition to hydrology, water quality, ecology, risk and uncertainty, environmental impact, etc. (e.g., Sivapalan et al., 1996a, b, c; Schneiderman et al., 2002).

- The ready availability on Internet and CD-ROM of data describing the land surface, especially digital elevation data for land surface terrain, has made it practical for the first time to delineate catchments in a few minutes in an automated way, and to compute the hydrologic properties of these catchments. The ability to build an integrated spatial hydrologic data base for a particular region has greatly improved. This also makes the use of distributed models more practical. 
Comprehensive hydrologic simulation systems using GIS databases are now operational, and being used for analysis of basins of more than 1 million $\mathrm{km}^{2}$ in area, a task that would have been unthinkable only a few years ago.

- Some progress on integration of processes among different phases of the hydrologic cycle is being accomplished by formulating separate models for each phase and then using GIS spatial data handling capabilities to transfer results from one set of spatial model units to another.

At the same time, a number of formidable challenges still remain:

- The integration of hydrological processes, particularly integration of surface and groundwater flow, is not yet solved satisfactorily. Integration of processes over scales of space and time is not well understood.

- A coupled modelling system that links GCMs with macroscale hydrologic models through dynamic downscaling approaches (i.e., nested system) has been developed and applied to world's large river basins at continental and global scales (e.g. Vörösmarty et al., 1993; Liang et al., 1994). In order to evaluate the effect of climate change or land-use change at smaller scale and finer resolution, an integrated modelling system that links climate model (GCM/RCM) with hydrological model through statistical downscaling is needed.

- Water quality modelling in rivers and lakes is so complex that it is still largely being done using traditional simulation models supported by GIS data. There is not yet much intrinsic water quality modelling within GIS.

- The problem of parameter estimation still constitutes the largest obstacle to the successful application of water resources assessment models. Clearly, from an operational point of view, the full benefit of a conceptual model will only be realised to the extent that it is possible to synthesize data for ungauged catchments. Previous studies have shown that the existing regionalization methods need to be improved, uncertainty induced from transferring the regionalization scheme based on the sub-catchment scale to basin scale, from basin unit to rectangular grid unit of the similar size, and from one geographic/climatic region to the other need to be evaluated and quantified. Predictions in ungauged basins/sites will continuously be significantly uncertain. Therefore, the importance to quantify this uncertainty for allowing a mindful use of the predictions and for assessing the value of different model approaches and additional data to reduce the degree of uncertainty is to be emphasized. It is appropriate to continue research in this aspect.

\section{Acknowledgements}

The first author thanks VR (The Swedish Research Council) for supporting his research work by providing fund on an yearly basis. He also gratefully acknowledges CAS (The Chinese Academy of Sciences) for awarding him with "The Outstanding Overseas Chinese Scholars Fund". 


\section{References}

Abdulla, F. A. and Lettenmaier, D. P., 1997a, 'Development of regional parameter estimation equations for a macroscale hydrological model', J. Hydrol. 197, 230-257.

Abdulla, F. A. and Lettenmaier, D. P., 1997b, 'Application of regional parameter estimation schemes to simulate the water balance of a large continental river', J. Hydrol. 197, 258-285.

Alley, W. M., 1984, 'On the treatment of evapotranspiration, soil moisture accounting and aquifer recharge in monthly water balance models', Water Resour. Res. 20(8), 1137-1149.

Ambroise, B., Perrin, J. L., and Reutenauer, D., 1995, 'Multicriterion validation of a semidistributed conceptual model of the water cycle in the Facht Catchment (Vosges Massif, France)', Water Resour. Res. 31(6), 1467-1481.

Anderson, M. P. and Woessner, W. W., 1992, 'The role of postaudit in model validation', Adv. Water Res. 15, 167-173.

Arnell, N. W., 1992, 'Factors controlling the effects of climate change on river flow regimes in a humid temperate environment', J. Hydrol. 132, 321-342.

Arnell, N. W., 1999, 'A simple water balance model for the simulation of streamflow over a large geographic domain', J. Hydrol. 217 (3/4), 314-335.

Arnold, J. G., Muttiah, R. S., Srinivasan, R., and Allen, P. M., 2000, 'Regional estimation of base flow and groundwater recharge in the Upper Mississippi river basin', J. Hydrol. 227, 21-40.

Becker, A. and Braun, P., 1999, 'Disaggregation, aggregation and spatial scaling in hydrological modelling', J. Hydrol. 217, 239-252.

Bergström, S., 1976, 'Development and application of a conceptual runoff model for Scandinavian catchments', Department of Water Resources Engineering, Lund Institute of Technology, Bulletin Series A-52, Swedish Meteorological and Hydrological Institute, Norrköping, Sweden.

Bergström, S., 1990, 'Parametervärden för HBV-modellen I Sverige-Erfarenheter från modellkalibreringar under perioden 1975-1989', SMHI Report Hydrology No. 28, Swedish Metereological and Hydrological Institute, Norrköping, Sweden, 35 p (in Swedish).

Bergström, S., 1992, 'The HBV model-its structure and applications', SMHI RH Report No 4. Swedish Meteorological and Hydrological Institute, Norrköping, Sweden.

Beven, K., 1989, 'Change ideas in hydrology: The case of physically based models', J. Hydrol. 105, $157-172$.

Beven, K. J. and Kirkby, M. J., 1979, 'A Physically based variable contributing area model of basin hydrology', Hydrol. Sci. Bull. 24 (1), 43-69.

Beven, K. J., Kirkby, M. J., Schofield, N., and Tagg, A. F., 1984, 'Testing a physically-based flood forecasting model (TOPMODEL) for three U.K. catchments', J. Hydrol. 69, 119143.

Budyko, M. I., 1955, 'On the determination of evaporation from the land surface', Meteorol. Gdrol, 1, 52-58 (in Russian).

Budyko, M-I. and Zubenok, L. I., 1961, 'On the determination of evaporation from the land surface', Izv. Akad. Nauk SSSR Ser. Geogr. 6, 3-17.

Bultot, F. and Dupriez, G. L., 1976, 'Conceptual hydrologic model for an average-sized catchment area: Concepts and relationships', J. Hydrol. 29, 251-272.

Bultot, F., Coppens, A., Dupriez, G. L., Gellens, D., and Meulenberghs, F., 1988, 'Repercussions of a $\mathrm{CO}_{2}$-doubling on the water cycle and on the water balance: A case study for Belgium', J. Hydrol. 99, 319-347.

Bultot, F., Gellens, D., Spreafico, M., and Schädler, B., 1992, 'Repercussions of $\mathrm{CO}_{2}$ doubling on the water balance: A case study in Switzerland', J. Hydrol. 137, 199-208.

Burnash, R. J. C., Ferral, R. L., and McGuire, R. A., 1973, 'A generalized streamflow simulation system, conceptual modeling for digital computer', U.S. Department of Commerce, National Weather Service and State of California, Department of Water Resources, Sacramento, CA. 
Crawford, N. H. and Linsley, R. K., 1964, 'A conceptual model of hydrologic cycle', IAHS Publication No. 63, 573-587.

Dingman, S. L., 1994, Physical Hydrology, Prentice Hall, Inc., Englewood Cliffs, NJ.

Dolman, A. J., Hall, A. J., Kavvas, M. L., Oki, T., and Pomeroy, J. W. (eds), 2001, Soil-VegetationAtmosphere Transfer Schemes and Large-Scale Hydrological Models IAHS Publication No. 270.

Dooge, J. C. I., 1992, 'Hydrologic models and climate change', J. Geophys. Res. D3, (97), 2677-2686.

Dyck, S., 1983, 'Overview on the present status of the concepts of water balance models', IAHS Publication No. 148, 3-19.

Ewen, J. and Parkin, G., 1996, 'Validation of catchment models for predicting land-use and climate change impacts 1: Method', J. Hydrol. 175, 583-594.

Fernandez, W., Vogel, R. M., and Sankarasubramanian, A., 2000, 'Regional calibration of a watershed model', Hydrol. Sci. J. 45, 689-707.

Fleming, G., 1975, Computer Simulation Techniques in Hydrology, Elsevier, New York.

Gottschalk, L., Beldring, S., Engeland, K., Tallaksen, L., Saelthun, N-R, Kolberg, S., and Motovilov, Y., 2001, 'Regional/macroscale hydrological modelling: A Scandinavian experience', Hydrol. Sci. J. 46 (6), 1-23.

Guo, S., Wang, J. and Yang, J., 2001, 'A semi-distributed hydrological model and its application in a macroscale basin in China', IAHS Publication No. 270, 167-174.

Hendrickson, J. D., Sorooshian, S., and Brazil, L. E., 1988, 'Comparison of Newton-Type and direct search algorithms for calibration of conceptual rainfall-runoff models', Water Resour. Res. 24(5), 691-700.

Hultcrantz, K. (ed), 1997, 'Comprehensive Assessment of Freshwater Resources of the World. The final report (E/CN.17/1997/9), prepared by a Steering Committee consisting of representatives for UN/DPCSD, UN/DDSMS, FAO, UNEP, WMO, UNESCO, WHO, UNDP, UNIDO, The World Bank. Stockholm Environment Institute, 59 pp',

IAHR, 1994, 'Publication of guidelines for validation documents and call for discussion', Int. Assoc. Hydraul. Res. Bull. 11, 41.

James, L. D., 1972, 'Hydrologic modelling, parameter estimation and watershed characteristics', J. Hydrol. 17, 283-307.

Jarboe, J. E. and Haan, C. T., 1974, 'Calibrating a water yield model for small ungaged watersheds', Water. Resour. Res. 10(2), 256-262.

Kim, W., Arai, T., Kanae, S., Oki, T., and Musiake, K., 2001, 'Application of the simple biosphere model (sib2) to a paddy field for a period of growing season in GAME-tropics', J. Meteo. Soc. Jpn. 79(1B), 387-400.

Kite, G. W., Dalton, A., and Dion, K., 1994, 'Simulation of streamflow in a macroscale watershed using general circulation model data', Water Resour. Res. 30, 1547-1599.

Klemes, V., 1986, 'Operational testing of hydrological simulation', Hydrol. Sci. J. 31, 13-24.

Leavesley, G. H., 1994, 'Modelling the effects of climate change on water resources-A review', Climatic Change 28, 159-177.

Liang, X., Lettenmaier, D. P., Wood, E., and Burges, S. J., 1994, 'A simple hydrologically based model of land surface water and energy fluxes for general circulation models', J. Geophys. Res. 99(D7), 14415-14428.

Liston, G. E., Sud, Y. C., and Wood, E. F., 1994, 'Evaluating GCM land surface hydrology parameterisations by computing river discharges using a runoff routing model: Application to the Mississippi Basin', J. Appl. Meteorol. 33, 394-404.

Loague, K. M., 1990, 'R-5 revisited 2. Reevaluation of a quasi-physically based rainfall-runoff model with supplemental information', Water Resour. Res. 21, 973-987.

Loaiciga, H. A., Valdes, J. B., Vogel, R., Garvey, J., and Schwarz, H., 1996, 'Global warming and the hydrologic cycle', J. Hydrol. 174, 83-127. 
Ma, X., Fukushima, Y., Hiyama, T., Hashimoto, T., and Ohata, T., 2000, 'A macro-scale hydrological analysis of the Lena River basin', Hydrol. Process. 14, 639-651.

Magette, W. L., Shanholtz, V. O., and Carr, J. C., 1976, 'Estimating selected parameters for the Kentucky watershed model from watershed characteristics', Water Resour. Res. 12(3), 472476.

Maidment, D. R., 1996, 'GIS and hydrologic modelling: An assessment of progress. Presented at The Third International Conference on GIS and Environmental Modeling', January 22-26, Santa Fe, New Mexico.

Matheussen, B., Kirschbaum, R. L., Goodman, I. A., O’Donnell, G. M., and Lettenmaier, D. P., 2000, 'Effects of land cover change on streamflow in the interior Columbia River basin (U.S.A. and Canada)', Hydrol. Process. 14, 867-885.

Mintz, Y. and Walker, G. K., 1993, 'Global fields of soil moisture and land surface evapotranspiration derived from observed precipitation and surface air temperature', J. Appl. Meteorol. 32, 13051334.

Müller-Wohlfeil, Dirk-I., Xu, C-Y, and Iversen, H. L., 2003, 'Estimation of monthly river discharge from Danish catchments', Nordic Hydrol. 34(4), 295-320.

Nash, J. E. and Sutcliffe, J., 1970, 'River flow forecasting through conceptual models Part 1. A discussion of principles', J. Hydrol. 10, 282-290.

Nash, L. and Gleick, P., 1993, 'The Colorado River basin and climate change. Rep', EPA 230-R-93009, United States Environmental Agency, Washington, DC.

Nathan, R. J., McMahon, T. A., and Finlayson, B. L., 1988, 'The impact of the Greenhouse effect on catchment hydrology and storage-yield relationships in both winter and summer rainfall zones', In G. I. Pearman (ed), Greenhouse, Planning for Climate Change, Division of Atmospheric Research, CSIRO, East Melbourne, Australia.

Nemec, J. and Schaake, J., 1982, 'Sensitivity of water resources system to climate variation', Hydrol. Sci. J. 2, 327-343.

Ng, H. Y. F. and Marsalek, J., 1992, 'Sensitivity of streamflow simulation to changes in climatic inputs', Nordic Hydrol. 23, 257-272.

Nijssen, B., Lettenmaier, D. P., Liang, X., Wetzel, S. W., and Wood, E., 1997, 'Streamflow simulation for continental-scale river basins', Water Resour. Res. 33(4), 711-724.

Ol'dekop, E. M., 1911, 'On evaporation from the surface of river basins', Tr. Meteorol. Observ. Iur'evskogo Univ. Tartu., 4.

Oreskes, N., Shrader-Frechette, K., Belitz, K., 1994, 'Verification, validation and confirmation of numerical models in earth sciences', Sciences 264, 641-646.

Pickup, G., 1977, 'Testing the efficiencies of algorithms and strategies for automatic calibration of rainfall runoff models', Hydrol. Sci. Bull. 22(2), 257-274.

Pike, J. G., 1964, 'The estimation of annual runoff from meteorological data in a tropical climate', $J$. Hydrol. 2, 116-123.

Porter, J. W. and McMahon, T. A., 1971, 'A model for the simulation of streamflow data from climatic records', J. Hydrol. 13, 297-324.

Refsgaard and Knudsen, 1996, 'Operational validation and intercomparison of different typs of hydrological models', Water Resour. Res. 32(7), 2189-2202.

Refsgaard, J. C., 1997, 'Parameterisation, calibration and validation of distributed hydrological models', J. Hydrol. 198, 69-97.

Rosenbrock, H. H., 1960, 'An automatic method of finding the greatest of least value of a function', Comput. J. 3, 175-184.

Rosso, R., 1994, 'An introduction to spatially distributed modelling of basin response', in R. Rosso, A Peano, I. Becchi, G. A. Bemporad (eds), Advances in Distributed Hydrology, Water Resources Publications, Portland, OR, USA, pp. 3-30. 
Rowntree, P., 1989, The Needs of Climate Modellers for Water Runoff Data. Workshop on Global Runoff Data Sets and Grid Estimation, 10-15 November 1988, Koblenz. World Climate Programme, WMO, June 1989, Geneva.

Schaake, J. C. and Liu, C., 1989, 'Development and application of simple water balance models to understand the relationship between climate and water resources. New Directions for Surface Water Modeling (Proceedings of the Baltimore Symposium, May 1989)', IAHS Publication No. 181.

Schneiderman, E. M., Pierson, D. C., Lounsbury, D. G., and Zion, M. S., 2002, 'Modelling the hydrochemistry of the Cannonsville watershed with generalized watershed loading functions (GWLF)', J. Am. Water Resour. Assoc. 38(5), 1323-1347.

Schreiber, P., 1904, 'On the relationship between precipitation and the runoff of rivers in Central Europe', Z. Meteorol. 21, 441-452.

Seibert, J., 1999, 'Regionalisation of parameters for a conceptual rainfall-runoff model', Agricultural and Forest Meteorology 98-99 pp. 279-293.

Seibert, J., 2000, 'Multi-criteria calibration of a conceptual rainfall-runoff model using a genetic algorithm', Hydrol. Earth Sys. Sci. 4(2), 215-224.

Servat, E. and Dezetter, A., 1993, 'Rainfall-runoff modelling and water resources assessment in north-western Ivory Coast. Tentative extension to ungauged catchments', J. Hydrol.148, 231248.

Shuttleworth, J. W., 1993, 'Evaporation. Handbook of Hydrology’, D. R. Maimdent Editor, McGrawHill, Inc.

Singh, V. P. (ed), 1995, 'Computer Models of Watershed Hydrology', Water Resources Publications, Littleton, Colorado.

Singh, V. P. and Frevert, D. K., (eds), 2002a, 'Mathematical Models of Large Watershed Hydrology', Water Resources Publications, Highlands Ranch, Colorado.

Singh, V. P. and Frevert, D. K. (eds), 2002b, 'Mathematical Models of Small Watershed Hydrology and Applications', Water Resources Publications, Highlands Ranch, Colorado.

Singh, V. P. and Woolhiser, D. A., 2002, 'Mathematical modeling of watershed hydrology', J.Hydrol. Eng. 7, 270-292.

Sivapalan, M., Ruprecht, J. K., and Viney, N. R., 1996a, 'Water and salt balance modelling to predict the effects of land-use changes in forested catchments. 1. Small catchment water balance model. Hydrol. Process. 10, 393-411.

Sivapalan, M., Viney, N. R., and Jeevaraj, C. G., 1996b, Water and salt balance modelling to predict the effects of land-use changes in forested catchments. 3. Coupled model of water and salt balances. Hydrol. Process. 10, 413-428.

Sivapalan, M., Viney, N. R., and Jeevaraj, C. G., 1996c, 'Water and salt balance modelling to predict the effects of land-use changes in forested catchments. 3. The large catchment model', Hydrol. Process. 10, 429-446

Sorooshian, S., V. K. Gupta and J. L. Fulton, 1983, 'Evaluation of maximum likelihood estimation techniques for conceptual rainfall-runoff models: Influence of calibration data variability and length on model credibility', Water Resour. Res. 10(1), 251-259.

Stamm, J. F., Wood, E. F., and Lettenmaier, D. P., 1994, 'Sensitivity of a GCM simulation of global climate to the representation of land-surface hydrology', J. Climate 7, 1218-1239.

Thornthwaite, C. W., 1948, 'An approach toward a rational classification of climate', Geogr. Rev. 38(1), 55-94.

Todini, E., 1996, 'The ARNO rainfall-runoff model', J. Hydrol. 175, 339-382.

Tung, Y. K., Yeh, K. C., and Yang, J. C., 1997, 'Regionalization of unit hydrograph parameters: 1. Comparison of regression analysis techniques', Stoch. Hydrol. Hydraul. 11, 145-171.

Turc, L., 1954, 'The water balance of soils', Relation between precipitation evaporation and flow. Ann. Agron. 5, 491-569. 
U.S. Environmental Protection Agency (U.S.E.P.A.), 1984, Users manual for hydrological simulation program-FORTRAN (HSPF), EPA-600/3-84-066, Environmental Research Laboratory, Athens, GA.

Vandewiele, G. L. and Elias, A., 1995, 'Monthly water balance of ungauged catchments obtained by geographical regionalization', J. Hydrol. 170, 277-291.

Vehviläinen, B. and Lohvansuu, J., 1991, 'The effects of climate change on discharges and snow cover in Finland', Hydrol. Sci. J. 36,109-121.

Vörösmarty, C. J., Gutowski, W. J., Person, M., Chen, T.-C., and Case, D., 1993, 'Linked atmospherehydrology models at the macroscale', IAHS Publication No. 214, 3-27.

Watson, F. G. R., Vertessy, R. A., and Grayson, R. B., 1999, 'Large-scale modelling of forest hydrological processes and their long-term effect on water yield', Hydrol. Process. 13, 689-700.

Weeks, W. D. and Ashkanasy, N. M., 1983, 'Regional parameters for the Sacramento Model: A case study', Hydrology and Water Resources Symposium, Hobart.

Wen, C.-G. and Lee, C.-S., 1998. 'A neural network approach to multiobjective optimization for water quality management in river basin', Water Resour. Res. 34(3), 427-436.

Wilby, R. L., Greenfield, B., and Glenny, C., 1994, 'A coupled synoptic-hydrological model for climate change impact assessment', J. Hydrol., 153, 265-290.

Wilkinson, W. B. (Editor), 1993. Macroscale Modelling of the Hydrosphere. IAHS Publ. 212.

Wood, E. F. (Editor), 1991, 'Land Surface-Atmospheroc Interactions for Climate Modelling: Observations', Models and Analysis. Kluwer Academic Publ. 314p.

Wood, E. F., Lettenmaier, D. P., and Zartarian, V. G., 1992, 'A land-surface hydrology parameterisation with subgrid variability for general circulation models', J. Geophys. Res. 97, (D3), 2717-2728.

Xu C.-Y. and Singh, V. P., 1998, 'A review on monthly water balance models for water resources investigations', Water Resour. Manage. 12, 31-50.

Xu, C.-Y., Seibert, J., and Halldin, S. 1996, 'Regional water balance modelling in the NOPEX area: Development and application of monthly water balance models', J. Hydrol. 180, 211-236.

Xu, C.-Y., 1999a, 'Operational testing of a water balance model for predicting climate change impacts', Agri. Forest Meteorol. 98/99(1-4), 295-304.

Xu, C.-Y., 1999b, 'Estimation of parameters of a conceptual water balance model for ungauaged catchments', Water Resour. Manage. 13(5), 353-368.

Xu, C.-Y., 1999c, 'Climate change and hydrologic models: A review of existing gaps and recent research developments', Water Resour. Manage. 13(5), 369-382.

Xu, C.-Y., 2000, 'Modelling the effects of climate change on water resources in central Sweden', Water Resour. Manage. 14, 177-189.

$\mathrm{Xu}, \mathrm{C} .-\mathrm{Y} ., 2003$, 'Testing the transferability of regression equations derived from small sub-catchments to large area in central Sweden', Hydrology and Earth System Sciences, 7(3), 317-324.

Yao, H. and Hashino, M., 2001, 'A completely-formed distributed rainfall-runoff model for the catchment scale', IAHS Publ. 270, 183-190.

Zhao, R. J., 1992, 'The Xinanjiang model applied in China', J. Hydrol. 135, 371-381.

Zhao, R. J., Zhang, Y. L., Fang, L. R., Liu, X. R., and Zhang, Q. S., 1980, 'The Xinanjiang model. Hydrological forecasting proceedings, Oxford Symposium, IAHS Publication No', 129, 351-356. 